\title{
PENGARUH PENAMBAHAN EKSTRAK BELIMBING WULUH (Averrhoa bilimbi L.) TERHADAP KARAKTERISTIK FISIK, MASA SIMPAN, DAN ORGANOLEPTIK PERMEN JELLY DAUN KERSEN
}

\author{
Veni Rori Setiawati ', Puspita Sari ${ }^{1}$ \\ ${ }^{1}$ Program Studi Teknologi Hasil Pertanian Fakultas Teknologi Pertanian Universitas Teknologi Sumbawa, \\ Co-author:veni.rori@uts.ac
}

\section{Paper Information}

History:

Received : 24-08- 2020

Accepted : 21-09-2020

\section{Keywords: \\ Starfruit \\ Cherry leaf \\ Jelly candy \\ Organoleptic}

Shelf life

ABSTRACT

Abstrak: Permen jelly merupakan permen yang terbuat dari komponen air atau sari buah, flavor, gula dan bahan pembentuk gel. Selain dari sari buah-buahan, permen jelly dapat dibuat dari bahan dasar sari daun. Salah satu daun yang dapat dimanfaatkan adalah daun kersen. Permen jelly yang ada umumnya belum menggunakan bahan alami sebagai pewarna dan rasa. Buah-buahan yang dapat digunakan sebagai bahan alami dalam pembuatan permen jelly adalah belimbing wuluh. Penelitian ini bertujuan untuk mengetahui pengaruh penambahan ekstrak belimbing wuluh terha dap mutu fisik, masa simpan, dan organoleptik permen jelly daun kersen. Penelitian ini menggunakan Rancangan Acak Lengkap (RAL) dengan 1 faktor yaitu konsentrasi ekstrak belimbing wuluh (0\%,5\%,10\%, 15\% dan 20\%). Hasil penelitian ini menunjukkan bahwa penambahan ekstrak belimbing wuluh tidak berpengaruh nyata terhadap mutu fisik (warna) permen jelly daun kersen. Pada pengujian masa simpan, penambahan ekstrak belimbing wuluh memberikan pengaruh nyata, dimana perlakuan terbaik yaitu pada konsentrasi ekstrak belimbing wuluh $15 \%$ dan $20 \%$. Pada uji organoleptik penambahan ekstrak belimbing wuluh tidak berpengaruh nyata terhadap tingkat kesukaan (hedonik) serta tingkat penerimaan (skoring) terhadap tekstur, namun mempengaruhi tingkat penerimaan panelis terhadap warna, aroma, dan rasa permen jelly daun kersen. Perlakuan terbaik terhadap tingkat penerimaan panelis untuk warna yaitu pa da konsentrasi $0 \%$ menghasilkan permen jelly yang berwarna coklat kekuningan serta Aroma dan rasa permen jelly terbaik yaitu pa da konsentrasi $20 \%$ menghasilkan permen jelly yang beraroma belimbing wuluh agak beraroma kersen dengan rasa manis agak pahit.
\end{abstract}

\begin{abstract}
Jelly is a candy made from components of water or fruit juice, flavor, sugar and gelling ingredients. Apart from fruit juice, jelly candy can be made from the basic ingredients of leaf extracts. One of the leaves that can be used is Muntingia calabura L. leaves. The existing jelly candies generally do not use natural ingredients as colorings and flavors. Fruits that can be used as natural ingredients in making jelly candy are Averrhoa bilimbi L. This study aims to determine the effect of adding starfruit extract to the physical quality, shelf life, and organoleptic of Muntingia calabura L. leaves jelly candy. This study used a Completely Randomized Design (CRD) with 1 factor, namely the concentration of Averrhoa bilimbi $L$ extract $10 \%, 5 \%, 10 \%, 15 \%$ and 20\%). The results of this study indicate that the addition of Averrhoa bilimbi $L$ extract does not significantly affect the physical quality (color) of Muntingia calabura L. leaves jelly candy. In the shelf life test, the addition of Averrhoa bilimbi $L$ extract gave a real effect, where the best treatment was the concentration of Averrhoa bilimbi L. extract 15\% and 20\%. In the organoleptic test, the addition of Averrhoa bilimbi $L$ extract did not significantly affect the level of preference (hedonic) and the level of acceptance (scoring) of the texture, but it did affect the level of panelist acceptance of the color, aroma, and taste of Muntingia calabura L. leaves jelly candy. The best treatment of panelist acceptance level for color is at a concentration of $0 \%$ producing jelly candy with a yellowish-brown color and the best aroma and taste of jelly candy at a concentration of $20 \%$ producing jelly Averrhoa bilimbi L -flavored jelly candy with a slightly bitter sweet taste with a slightly bitter sweetness.
\end{abstract}

\section{A. LATAR BELAKANG}

Permen atau kembang gula adalah jenis makanan selingan dalam bentuk padat, dibentuk dari gula atau pemanis lain dengan atau tanpa bahan makanan lain dan bahan makanan tambahan yang diizinkan. Kembang gula diklasifikasikan dalam empat jenis yaitu: kembang gula keras, kembang gula lunak, kembang gula karet dan kembang nirgula (Wahyuni, 2010). Permen jelly termasuk kembang gula lunak yang mempunyai tekstur kenyal dan elastis. Permen jelly merupakan permen yang terbuat dari komponen air atau sari buah, flavor, gula dan bahan pembentuk gel (Sinurat and Murniyati, 2014). Permen jelly umumnya terbuat dari rumput laut dan sari buahbuahan. Selain dari sari buah-buahan, permen jelly 
dapat dibuat dari bahan dasar sari daun. Salah satu daun yang dapat dimanfaatkan adalah daun kersen (Marfungah et al., 2019).

Secara tradisional, selain buahnya yang dapat langsung dikonsumsi maupun diolah menjadi selai, ternyata daun kersen juga memiliki khasiat. Menurut Verdayanti (2009), kersen merupakan salah satu tanaman yang diduga memiliki substansi aktif sebagai anti diabetes yaitu asam askorbat, serat niasin dan betakaroten (Tyas Eka, 2009). Daun kersen mengandung kelompok senyawa atau lignan antara lain flavonoid, tannin, triterpene, saponin, dan polifenol yang menunjukkan aktivitas antioksidan (Zakaria et al., 2011). Pengolahan daun kersen telah banyak dilakukan oleh masyarakat, diantaranya minuman sari dan teh seduh. Pengolahan minuman sari daun kersen dapat dilakukan dengan cara fermentasi menjadi minuman kombucha. Pengolahan daun kersen menjadi teh seduh dapat dilakukan dengan cara sederhana yaitu dengan menuangkan air panas pada daun kersen kemudian diaduk lalu disaring dan siap dikonsumsi. Selain minuman sari dan teh seduh, daun kersen juga dapat diolah menjadi permen jelly. Pembuatan permen jelly daun kersen dengan konsentrasi ekstrak daun kersen yaitu $20 \%$, $40 \%$, 60\%, 80\%, dan 100\%, menghasikan permen jelly daun kersen terbaik dengan penambahan ekstrak daun kersen $100 \%$. Hasil kimiawinya adalah kadar air $22.63 \%$, gula reduksi $3.8173 \%$, kadar abu $2.43 \%$, tekstur (fisik) $15.52 \%$, kecerahan $17.60 \%$, protein $8.796 \%$, rasa $4.30 \%$, aroma $4.15 \%$, warna $4.75 \%$ dan tekstur 4.75\%. Damayanti et al., (2019) melaporkan bahwa tekstur permen jelly daun kersen bertekstu kenyal dan halus yang diperoleh dari penyaringan gelatin, adonan dioven selama 10 menit, dan permen jelly didiamkan dalam kulkas selama 24 jam (Damayanti et al., 2019). Permen jelly banyak memiliki variasi rasa, diantaranya permen jelly dengan rasa buah-buahan seperti permen jelly nanas, permen jelly strawbery, permen jelly anggur, permen jelly mangga dan lain-lain.

Berdasarkan pengamatan di pasaran, permen jelly yang ada umumnya belum menggunakan bahan alami sebagai pewarna dan perasa. Berbagai buah-buahan dapat digunakan sebagai bahan alami dalam pembuatan permen jelly, salah satunya buah belimbing wuluh. Pengolahan daun kersen menjadi permen jelly dengan penambahan ekstrak buah belum pernah dilakukan. Oleh sebab itu, pembuatan permen jelly daun kersen akan dipadukan dengan ekstrak buah belimbing wuluh (Averrhoa bilimbi L.).

Belimbing wuluh (Averrhoa bilimbi L.) merupakan buah yang banyak tersebar di Indonesia sebagai tanaman perkarangan rumah yang belum dibudidayakan. Penambahan ekstrak buah belimbing wuluh dalam permen jelly dapat digunakan sebagai pengawet alami. Wikanta (2011) menyatakan bahwa air perasan belimbing wuluh mengandung senyawa aktif berupa flavonoid dan triterpenoid yang berperan sebagai zat anti bakteri (Aprilliani and Ginting Suka, 2017; Fitri, 2017). Di Sumbawa belimbing wuluh dikenal dengan nama "Binang". Masyarakat Sumbawa menggunakan belimbing wuluh sebagai bahan dalam pembuatan makanan atau bahan pelengkap masakan khas daerah Sumbawa seperti sepat, urap, dan sambal asam binang. Selain pemanfaatan yang sudah dikenal masyarakat, belimbing wuluh juga dimanfaatkan sebagai bahan baku dalam pembuatan minuman, sehingga orang tidak nyaman untuk mengkonsumsinya langsung sehingga berpotensi untuk dimanfaatkan dalam produk permen jelly (Fitri, 2017).

Pemanfaatan buah belimbing wuluh dalam permen jelly diharapkan dapat memberikan nilai tambah belimbing wuluh. Buah belimbing wuluh yang digunakan untuk olahan permen jelly adalah buah yang sudah matang atau tua, karena belimbing memiliki kandungan vitamin $\mathrm{C}$ dan asam yang tinggi. Tampilan warna dan rasa asam yang khas dari belimbing wuluh dapat dijadikan sebagai flavor alami permen jelly (Roikah et al., 2016). Kombinasi daun kersen sebagai pewarna dan belimbing wuluh sebagai perasa diharapkan menjadi upaya perbaikan kualitas organoleptik jelly. Rasa pahit yang muncul dari daun kersen diharapkan tersamarkan dengan rasa asam dari belimbing wuluh dan gula ((Buhian et al., 2016; Fitri, 2017). Sejauh ini belum diketahui daya terima panelis terhadap produk olahan tersebut. Oleh sebab itu perlu dilakukan penelitian tentang pengaruh penambahan ekstrak belimbing wuluh (Averrhoa bilimbi L.) terhadap karakteristik fisik, organoleptik dan masa simpan permen jelly daun kersen (Muntingia calabura). Hasil penelitian diharapkan menjadi inovasi produk pangan berupa permen jelly yang dapat diterima konsumen, bermanfaat untuk kesehatan dan dapat berkembang sebagai unit usaha pengolahan jelly kersen dan belimbing wuluh.

\section{B. METODE PENELITIAN}

\section{Alat dan Bahan Penelitian}

Alat yang digunakan dalam penelitian ini ada dua bagian, yaitu alat untuk pembuatan permen jelly dan alat untuk analisis. Alat untuk pembuatan permen jelly antara lain: baskom, panci, kemasan gelas (cup plastik), blender, gelas ukur, saringan, pisau, timbangan analitik, kompor, stopwatch, termometer batang, pengaduk, dan nampan. Alat yang digunakan untuk analisis adalah aplikasi Color Analysis.

Bahan yang digunakan dalam penelitian ini adalah daun kersen segar diambil pangkal daun ke 510 dari pucuk (daun tua) dan belimbing wuluh matang yang didapat dari daerah Sumbawa, Desa Lamenta, Kecamatan Empang. Air kemasan, sukrosa, sirup glukosa, karagenan jenis kappa, dan pektin yang diperoleh melalui aplikasi belanja online.

\section{Tahapan Penelitian}

Pembuatan sari daun kersen yaitu dengan cara dilakukan blansing daun kersen dan air dengan perbandingan 1:5 pada suhu $90^{\circ} \mathrm{C}$ selama 5 menit. Kemudian dilakukan penyaringan untuk mendapatkan sari daun kersen.

Pembuatan ekstrak buah belimbing wuluh berdasarkan metode Candra (2019) yang telah dimodifikasi yaitu ekstraksi dilakukan dengan maserasi menggunakan pelarut air (suhu ruang) untuk memperoleh ekstrak buah belimbing wuluh (Candra and Widodo, 2012). Sebanyak $100 \mathrm{~g}$ buah belimbing wuluh ditimbang dan dicuci dengan air mengalir sampai bersih, kemudian haluskan buah 
belimbing wuluh menggunakan blender dengan menambahkan $100 \mathrm{ml}$ air sampai halus. Lalu, saring dengan menggunakan saringan untuk memperoleh ekstrak buah belimbing wuluh.

Pembuatan permen jelly daun kersen berdasarkan metode Marfungahet al., (2019) yang telah dimodifikasi. Sari daun kersen sebanyak $100 \mathrm{ml}$ ditambahkan sukrosa sebanyak 45\% (v/v) dan sirup glukosa $9 \%(\mathrm{v} / \mathrm{v})$ dimasukkan ke dalam panci kemudian larutan dipanaskan hingga mencapai suhu $80{ }^{\circ} \mathrm{C}$ (Marfungah et al., 2019). Setelah campuran merata ditambahkan pektin $2 \%$, karagenan $4 \%$, secara bertahap sambil diaduk hingga mencapai suhu $85^{\circ} \mathrm{C}$. Setelah suhu campuran mencapai $85^{\circ} \mathrm{C}$ api dimatikan. Kemudian ditambahkan ekstrak buah belimbing wuluh sesuai perlakuan (0\%, 5\%, 10\%, 15\%, 20\%) sambil diaduk. Setelah bahan tercampur rata, bahan dituangkan kedalam loyang atau cetakan yang sudah disiapkan. Kemudian didiamkan pada suhu ruang hingga dingin dan permen jelly terbentuk. Setelah itu dipotong.

\section{Analisis Permen Jelly}

Proses analisis dilakukan dengan bantuan aplikasi Color Analysis. Tahapan analisis warna dimulai dengan cara persiapan sampel-mengidentifikasi nilai $\mathrm{L}^{*}, \mathrm{a}^{*}, \mathrm{~b}^{*}$ dan ${ }^{\circ}$ Hue yang diperoleh dari hasil foto pada sampel (produk) sebanyak 3 kali pengulangan pada masing-masing konsentrasi. Lalu hasil foto produk dari aplikasi dicatat, selanjutnya menghitung nilai ${ }^{\circ}$ Hueuntuk mengetahui perubahan warna pada permen jelly. Nilai ${ }^{\circ} \mathrm{Hue}$ diperoleh dari rumus: ${ }^{\circ} \mathrm{Hue}=$ $\operatorname{tg}^{1}(\mathrm{~b} / \mathrm{a})$

Penilaian organoleptik dengan metode hedonik dan skoring merupakan suatu metode pengujian yang didasarkan atas tingkat kesukaan dan tingkat penerimaan panelis terhadap sampel yang disajikan. Uji dengan metode hedonik dan skoring dilakukan pada 30 panelis tidak terlatih, dengan menggunakan lima skala yaitu 1 (sangat tidak suka), 2 (tidak suka), 3 (Agak suka), 4 (suka), dan 5 (sangat suka). Jenis pengujian yang dilakukan dalam uji organoleptik ini adalah metode tingkat kesukaan dan tingkat penerimaan panelis terhadap warna, aroma, rasa, dan tekstur yang dihasilkan dari masing-masing perlakuan (Marfungah et al., 2019).

Pengujian masa simpan produk permen jelly ekstrak daun kersen dilakukan secara visual pada suhu ruang yang bertujuan untuk mengetahui mikroba yang tumbuh pada produk permen jelly daun kersen yang dilakukan secara berkala setiap hari sampai diketahui perkembangan mikroba yang bertujuan untuk mengetahui masa simpan pada permen jelly.

\section{Rancangan Percobaan}

Rancangan percobaan yang digunakan pada penilitian ini adalah Rancangan Acak Lengkap (RAL) dengan satu faktor yaitu 5 perlakuan konsentrasi ekstrak buah belimbing wuluh. Konsentrasi ekstrak buah belimbing wuluh yang digunakan yaitu, Ko = $\mathrm{O} \%, \mathrm{~K} 1=5 \%, \mathrm{~K} 2=10 \%, \mathrm{~K}_{3}=15 \%, \mathrm{~K} 4=20 \%$. Hasil penelitian ini telah dianalisa dengan menggunakan Analysis of Variance (ANOVA). Setiap perlakuan dilakukan sebanyak 3 kali pengulangan dengan total unit percobaan sebanyak 15 unit percobaan. Jika terdapat perbedaan pada unit percobaan, maka dilakukan uji lanjut Duncan dengan taraf signifikan $5 \%$.

\section{HASIL DAN PEMBAHASAN}

\section{Mutu Fisik (Warna)}

Parameter warna yang ujidalam penelitian ini meliputi nilai kecerahan (L) dan nilai hue dari permen jelly daun kersen. Rerata nilai kecerahan (L) permen jelly daun kersen pada perlakuan penambahan konsentrasi ekstrak belimbing wuluh berkisar antara 27,73 sampai 40,80. Sedangkan rerata nilai ${ }^{\circ} \mathrm{Hue}$ berkisar antara 59,33 sampai 69,83. Rerata nilai kecerahan (L) dan hue permen jelly daun kersen disajikan pada Gambar 1.

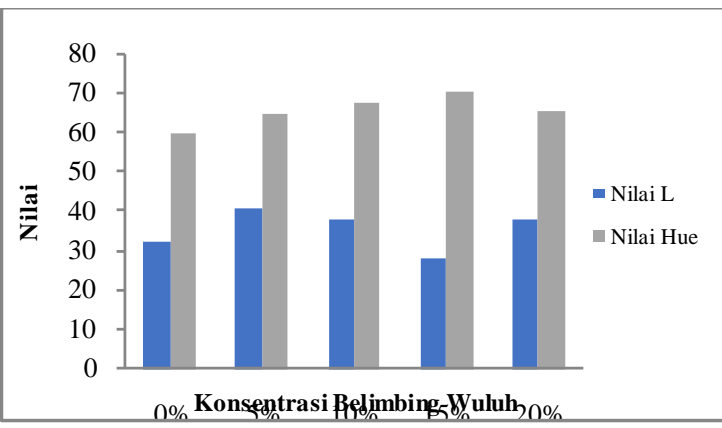

Gambar 1. Rerata Nilai L dan Hue Jelly daunkersen

Gambar 1 menunjukkan bahwa nilai tertinggi rata-rata kecerahan (L) permen jelly ekstrakdaun kersen pada perlakuan penambahan konsentrasi ekstrak belimbing wuluh terdapat pada permen jelly dengan konsentrasi ekstrak belimbing wuluh $5 \%$. Nilai terendah rata-rata kecerahan (L) permen jelly daun kersen pada perlakuan penambahan konsentrasi ekstrak belimbing wuluh terdapat pada permen jelly dengan konsentrasi ekstrak belimbing wuluh $15 \%$. Hasil analisis variansi menunjukkan bahwa perbedaan penambahan konsentrasi ekstrak belimbing wuluh tidak berbeda nyata terhadap nilai L (Kecerahan) warna permen jelly daun kersen, sehingga tidak dilakukan uji lanjut. Hal ini karena tidak adanya penambahan zat yang dapat mempengaruhi warna. Sedangkan rata-rata nilai hue permen jelly daun kersen pada perlakuan penambahan konsentrasi ekstrak belimbing wuluh berkisar antara 59,33 sampai 69,83, yang artinya perhitungan nilai ${ }^{\circ} \mathrm{Hue}$ secara keseluruhan permen jelly daun kersen pada berbagai konsentrasi memiliki kisaran warna kuning kemerahan (yellow red). Warna kemerahan pada permen jelly daun kersen diduga disebabkan adanya kandungan senyawa tannin daun kersen. Tanin disebut juga asam tanat dan asam galonat. Tanin dapat tidak berwarna, berwarna kuning sampai berwarna coklat. Secara organoleptik warna yang ketika ketika dideteksi menggunakan alat berwarna coklat oleh indera penglihatan manusia berubah warna menjadi merah (Amelia, 2015).

\section{Pengamatan Jamur}

Uji daya simpan dilakukan untuk mengetahui masa simpan permen jelly dengan mengamati pertumbuhan jamur permen jelly menggunakan metode pengamatan secara visual dengan berbagai 
perbedaan konsentrasi ekstrak belimbing wuluh (o\%, $5 \%, 10 \%, 15 \%$ dan $20 \%$ ) yang diamati selama 5 hari dengan 5 kali pengecekan. Pertumbuhan jamur permen jelly dengan berbagai perbedaan konsentrasi ekstrak belimbing wuluh dapat dilihat pada Tabel 1.

Tabel1.

\section{Pengamatan Masa Simpan Permen Jelly SecaraVisual}

\begin{tabular}{|c|c|c|c|c|c|c|}
\hline \multicolumn{2}{|c|}{\begin{tabular}{|l|} 
Perlakuan \\
\end{tabular}} & $\begin{array}{c}\text { Ko } \\
(\mathrm{o} \%)\end{array}$ & K1 (5\%) & $\begin{array}{c}\mathrm{K} 2 \\
(10 \%)\end{array}$ & $\begin{array}{c}\mathrm{K}_{3} \\
(15 \%)\end{array}$ & $\begin{array}{c}\mathrm{K} 4 \\
(20 \%)\end{array}$ \\
\hline \multirow{3}{*}{$\begin{array}{l}\text { Hari } \\
\text { Ke-1 }\end{array}$} & $\begin{array}{c}\text { Warn } \\
\text { a }\end{array}$ & - & - & - & - & - \\
\hline & \begin{tabular}{|c} 
Arom \\
a
\end{tabular} & - & - & - & - & - \\
\hline & $\begin{array}{c}\text { Tekst } \\
\text { ur }\end{array}$ & - & - & - & - & - \\
\hline \multirow{3}{*}{$\left|\begin{array}{c}\text { Hari } \\
\mathrm{Ke}- \\
2\end{array}\right|$} & $\begin{array}{c}\text { Warn } \\
\text { a }\end{array}$ & - & - & - & - & - \\
\hline & $\begin{array}{c}\text { Arom } \\
\mathrm{a}\end{array}$ & - & - & - & - & - \\
\hline & \begin{tabular}{|c} 
Tektu \\
$\mathrm{r}$
\end{tabular} & - & - & - & - & - \\
\hline \multirow{3}{*}{$\begin{array}{c}\text { Hari } \\
\text { Ke- } \\
3\end{array}$} & $\begin{array}{c}\text { Warn } \\
\text { a }\end{array}$ & - & - & - & - & - \\
\hline & $\begin{array}{c}\text { Arom } \\
\text { a }\end{array}$ & - & - & - & - & - \\
\hline & \begin{tabular}{|c|} 
Tekst \\
ur
\end{tabular} & - & - & - & - & - \\
\hline \multirow{3}{*}{$\begin{array}{c}\text { Hari } \\
\mathrm{Ke}- \\
4\end{array}$} & $\begin{array}{c}\text { Warn } \\
\text { a }\end{array}$ & \begin{tabular}{|c|} 
Ada \\
bercak \\
putih \\
(ditu \\
m buhi \\
jamur \\
)$(+)$ \\
\end{tabular} & \begin{tabular}{|c|} 
Ada \\
bercak \\
putih \\
(ditum \\
buhi \\
jamur) \\
$(+)$ \\
\end{tabular} & \begin{tabular}{|c|} 
Ada \\
bercak \\
putih \\
(ditum \\
buhi \\
jamur) \\
$(+)$ \\
\end{tabular} & - & - \\
\hline & $\begin{array}{c}\text { Arom } \\
\text { a }\end{array}$ & \begin{tabular}{|c|} 
Sediki \\
$t$ \\
tengik \\
$(+)$
\end{tabular} & $\begin{array}{l}\text { Sedikit } \\
\text { tengik } \\
(+)\end{array}$ & $\begin{array}{c}\text { Sedikit } \\
\text { tengik } \\
(+)\end{array}$ & - & - \\
\hline & $\begin{array}{c}\text { Tekst } \\
\text { ur }\end{array}$ & \begin{tabular}{|c|} 
Sediki \\
$t$ \\
kenyal \\
agak \\
lengke \\
$t(+)$
\end{tabular} & $\begin{array}{c}\text { Sedikit } \\
\text { kenyal } \\
\text { agak } \\
\text { lengket } \\
(+)\end{array}$ & $\begin{array}{c}\text { Sedikit } \\
\text { kenyal } \\
\text { agak } \\
\text { lengket } \\
(+)\end{array}$ & - & - \\
\hline \multirow{3}{*}{$\begin{array}{l}\text { Hari } \\
\text { Ke- } \\
5\end{array}$} & $\begin{array}{l}\text { Warn } \\
\text { a }\end{array}$ & $\begin{array}{c}\text { Ditum } \\
\text { buhi } \\
\text { jamur } \\
(++)\end{array}$ & 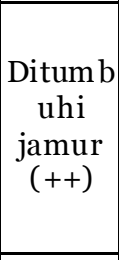 & $\underset{\substack{\text { Ditumb } \\
\text { jami } \\
(++)}}{\text { jamur }}$ & \begin{tabular}{|c|} 
Ada \\
bercak \\
putih \\
(ditum \\
buhi \\
jamur) \\
$(+)$ \\
\end{tabular} & $\begin{array}{c}\text { Ada } \\
\text { bercak } \\
\text { putih } \\
\text { (ditum } \\
\text { buhi } \\
\text { jamur) } \\
(+) \\
\end{array}$ \\
\hline & $\begin{array}{l}\text { Arom } \\
\text { a }\end{array}$ & $\begin{array}{c}\text { tengik } \\
(++)\end{array}$ & $\begin{array}{c}\text { tengik } \\
(++)\end{array}$ & $\begin{array}{c}\text { tengik } \\
(++)\end{array}$ & $\begin{array}{c}\begin{array}{l}\text { Sedikit } \\
\text { tengik } \\
(+)\end{array} \\
\end{array}$ & $\begin{array}{c}\text { Sedikit } \\
\text { tengik } \\
(+) \\
\end{array}$ \\
\hline & $\begin{array}{l}\text { Tekst } \\
\text { ur }\end{array}$ & $\begin{array}{c}\text { Sediki } \\
t \\
\text { lunak, } \\
\text { lengke } \\
t(++)\end{array}$ & $\begin{array}{l}\text { Sedikit } \\
\text { lunak, } \\
\text { lengket } \\
(++)\end{array}$ & $\begin{array}{c}\text { Sedikit } \\
\text { lunak, } \\
\text { lengket } \\
(++)\end{array}$ & $\begin{array}{c}\text { Sedikit } \\
\text { kenyal } \\
\text { agak } \\
\text { lengket } \\
(+)\end{array}$ & $\begin{array}{c}\text { Sedikit } \\
\text { kenyal } \\
\text { agak } \\
\text { lengket } \\
(+)\end{array}$ \\
\hline
\end{tabular}

Keterangan:

$(-)$ : Belum ditumbuhi jamur

$(+)$ : Sudah ditumbuhi jamur

$(++)$ : Pertumbuhan jamur meningkat

Berdasarkan pengujian secara visual, jamur dapat tumbuh selama proses penyimpanan. Permen jelly daun kersen hanya mempunyai masa simpan 3 hari (Tabel 1). Pada hari keempat sudah terdapat penyimpangan warna, aroma dan tekstur. Pengaruh kadar air permen jelly daun kersen terhadap pertumbuhan jamur berbanding lurus yang menyebabkan umur simpan produk pendek. Sedangkan permen jelly dengan penambahan konsentrasi ekstrak belimbing wuluh 15\% dan 20\% mempunyai masa simpan yang lebih lama (5 hari) karena ekstrak belimbing wuluh mengandung flavonoid yang dapat menghambat mikroba (anti bakteri) (Andriani, Ansharullah and Asyik, 2018).

\section{Pengujian Organoleptik Permen Jelly Daun Kersen}

Uji organoleptik oleh 30 panelis tidak terlatih terhadap uji kesukaan dan skoring. Skala penilaian adalah 1 (sangat tidak suka), 2 (tidak suka), 3 (Agak suka), 4 (suka), dan 5 (sangat suka) terhadap warna, aroma, rasa, dan tekstur sampeldari masing-masing perlakuan.

\subsection{Organoleptik Warna}

Warna merupakan salah satu faktor yang mempengaruhi makanan dilihat secara visual dan akan berpengaruh terhadap selera konsumen (Ahmad, Une and Bait, 2019). Gambar 2 memperlihatkan tingkat kesukaan dan penerimaan panelis terhadap jelly ekstrak daun kersen dan belimbing wuluh.

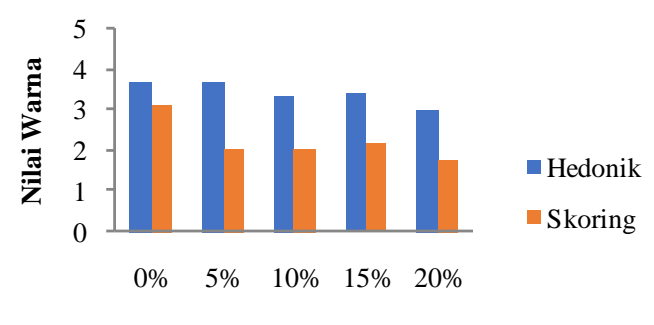

Konsentrasi Belimbing Wuluh

Gambar 2. Rerata Organoleptik warna

Rerata tingkat kesukaan panelis terhadap warna permen jelly ekstrak daun kersen dengan variasi penambahan ekstrak belimbing wuluh berkisar antara 3,00 (agak suka) sampai 3,66 (suka). Hasil analisis variansi menunjukkan bahwa perbedaan penambahan konsentrasi ekstrak belimbing wuluh tidak berpengaruh nyata terhadap tingkat kesukaan panelis pada warna permen jely ekstrak daun kersen, sehingga tidak dilakukan uji lanjut. Kesukaan terhadap warna merupakan hal pertama yang dipilih seseorang dalam memilih suatu produk.

Sedangkan tingkat penerimaan (uji skoring) berkisar antara 1,76 (kuning kecoklatan) sampai 3,16 (coklat). Hasil analisis variansi menunjukkan bahwa perbedaan penambahan konsentrasi ekstrak belimbing wuluh berpengaruh nyata terhadap tingkat penerimaan panelis pada warna permen jelly ekstrakdaun kersen, sehingga diperlukan uji lanjut. Hasil uji lanjut Duncan menunjukkan bahwa penambahan konsentrasi ekstrak belimbing wuluh o\% (tanpa penambahan ekstrak belimbing wuluh) berbeda 
nyata dengan konsentrasi $5 \%, 10 \%, 15 \%$ dan $20 \%$ Penambahan konsentrasi ekstrak belimbing wuluh $5 \%$ tidak berbeda nyata dengan konsentrasi 10\%, 15\% dan $20 \%$.

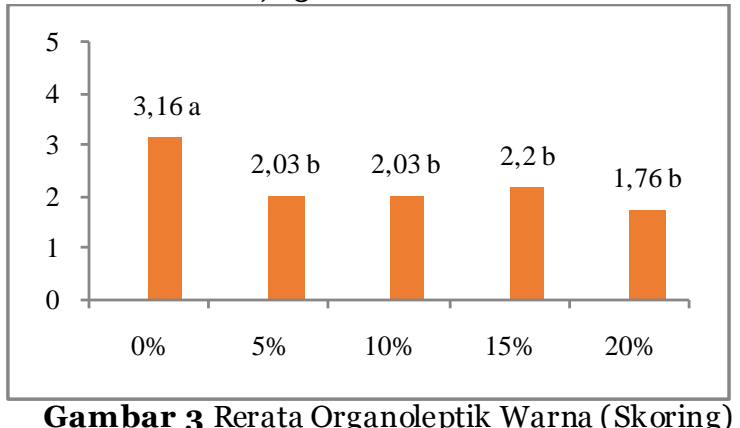

Berdasarkan Gambar 3, dapat dilihat bahwa tingkat penerimaan yang paling tinggi menurut panelis adalah permen jelly dengan konsentrasi ekstrak belimbing wuluh sebesar o\% $(3,16)$ yang masuk dalam kategori coklat, sedangkan tingkat penerimaan yang paling rendah adalah produk permen jelly dengan konsentrasi ekstrak belimbing wuluh sebesar $20 \%(1,76)$ yang masuk dalam kategori kuning kecoklatan. Hal tersebut diduga, perbedaan penambahan konsentrasi ekstrak belimbing wuluh akan menghasilkan warna yang sedikit cerah (kuning kecoklatan hingga kuning pucat). Warna kuning diduga disebabkan oleh adanya asam sitrat yang terkandung didalam belimbing wuluh (Roikah et al., 2016). Namun, tanpa penambahan ekstrak belimbing wuluh akan menghasilkan warna yang cenderung gelap (coklat). Oleh sebab itu, panelis lebih banyak menyukai produk dengan konsentrasi tanpa penambahan ekstrak belimbing wuluh karena sebagian besar panelis mengatakan warna coklat pada permen jelly cenderung lebih menarik.

\subsection{Organoleptik Aroma}

Aroma merupakan salah satu bagian penting pada suatu produk pangan yang dapat dijadikan sebagai parameter mutu. Selain itu, aroma juga dapat digunakan sebagai indikator terjadinya kerusakan pada produk. Pengujian ini dilakukan untuk mengetahui tingkat kesukaan (Hedonik) dan tingkat penerimaan (Skoring) terhadap aroma permen jelly ekstrak daun kersen yang dilakukan oleh 30 panelis tidak terlatih. Ratarata tingkat kesukaan dan penerimaan panelis terhadap aroma dari permen jelly ekstrak daun kersen dapat dilihat pada Gambar 4 .

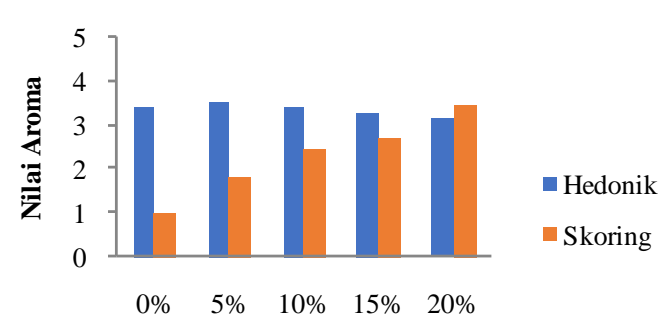

Konsentrasi Belimbing Wuluh

Gambar 4. Skor Rerata Organol eptik Aroma
Gambar 4 menunjukkan rata-rata tingkat kesukaan (uji hedonik) terhadap aroma permen jelly daun kersen dengan variasi penambahan konsentrasi ekstrak belimbing wuluh berdasarkan penilaian 30 orang panelis berkisar antara 3,16 (agak suka) sampai 3,53 (suka). Hasil analisis variansi menunjukkan bahwa perbedaan penambahan konsentrasi ekstrak belimbing wuluh tidak berbeda nyata terhadap tingkat kesukaan panelis pada aroma permen jelly, sehingga tidak dilakukan uji lanjut. Pada gambar terlihat bahwa aroma permen jelly tanpa penambahan ekstrak belimbing wuluh dan dengan penambahan ekstrak belimbing wuluh tidak memberikan perbedaan yang signifikan dikarenakan perbedaan aroma pada permen jelly tanpa penambahan dan dengan penambahan ekstrak belimbing wuluh relatif kecil.

Adapun tingkat penerimaan (uji skoring) berkisar antara 1,00 (beraroma kersen) sampai 3,50 (beraroma belimbing wuluh agak beraroma kersen). Hasil analisis variansi menunjukkan bahwa perbedaan penambahan konsentrasi ekstrak belimbing wuluh berpengaruh nyata terhadap tingkat penerimaan panelis pada aroma permen jelly daun kersen, sehingga diperlukan uji lanjut. Hasil uji lanjut duncan menunjukkan bahwa penambahan konsentrasi ekstrak belimbing wuluh $0 \%$ berbeda nyata dengan konsentrasi $5 \%, 10 \%, 15 \%$ dan $20 \%$. Konsentrasi ekstrak belimbing wuluh $5 \%$ berbeda nyata dengan Konsentrasi ekstrak belimbing wuluh $10 \%, 15 \%$ dan 20\%. Konsentrasi ekstrak belimbing wuluh $10 \%$ dan $15 \%$ tidak berbeda nyata namun berbeda nyata dengan konsentrasi $20 \%$.

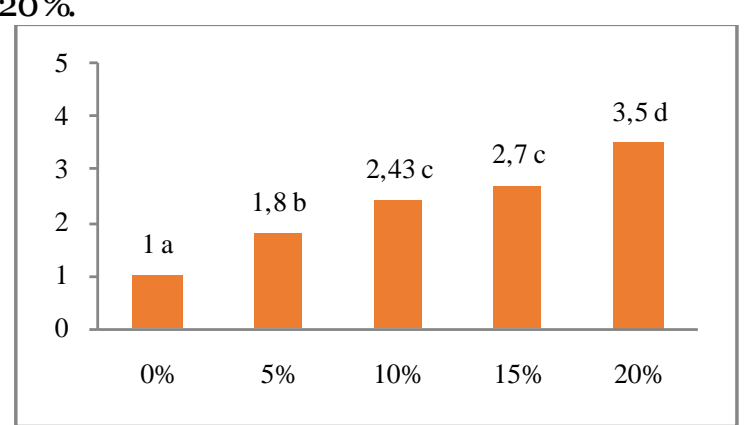

\section{Gambar 5. Skor Rerata Organoleptik Aroma}

Berdasarkan Gambar 5 dapat dilihat bahwa perbedaan konsentrasi ekstrak belimbing wuluh memiliki tingkat penerimaan yang berbeda-beda. Tingkat penerimaan yang paling tinggi berdasarkan penilaian panelis adalah perlakuan K4 (20\%) sebesar 3,50 yang masuk dalam kategori beraroma belimbing wuluh agak beraroma kersen, sedangkan tingkat penerimaan yang paling rendah adalah perlakuan Ko (o\%) sebesar 1,00 yang masuk dalam kategori beraroma kersen. Semakin tinggi penambahan ekstrak belimbing wuluh maka aroma buah belimbing wuluh semakin kuat dan penerimaan panelis terhadap aspek aroma cenderung meningkat. Aroma atau bau terdeteksi ketika senyawa volatil masuk dan melewati saluran 
hidung dan diterima oleh sistem olfaktori dan diteruskan ke otak (Meutia et al., 2015). Pino et al., (2004) telah mengisolasi komponen volatile dari belimbing wuluh dan berhasil mengidentifikasi 62 komponen volatil yang ada (Pino, Marbot and Bello, 2004). Pernyataan tersebut didukung oleh Pratiwi (2018) dimana alpha-pinenadanetil metoksifenil)-2-propenoat merupakan komponen volatil yang berperan dalam pembentukan aroma belimbing wuluh (Mahar Maligan, Dian Pratiwi and Dewanti Widyaningsih, 2019). Aroma permen jelly pada penelitian ini tidak dipengaruhi oleh bahan pendukung seperti sukrosa, sirup glukosa dan bahan penstabil yang digunakan dalam formulasi pembatan permen jelly tetapi dipengaruhi oleh aroma bahan baku yang digunakan yaitu daun kersen dan belimbing wuluh.

\subsection{Organoleptik Rasa}

Flavor atau rasa didefinisikan sebagai rangsangan yang ditimbulkan oleh bahan yang dimakan, yang dirasakan oleh indra pengecap atau pembau, serta rangsangan lainnya seperti perabaan dan penerimaan derajat panas oleh mulut (Ahmad, Une and Bait, 2019). Parameter rasa berperan dalam menentukan tingkat penerimaan dari suatu bahan pangan oleh konsumennya. Rasa diakibatkan oleh rangsangan yang diterima oleh lidah. Empat rangsangan utama adalah manis, asin, asam, dan pahit. Setiap rangsangan sebagian besar diterima pada bagian tertentu pada lidah. Pengujian ini dilakukan untuk mengetahui tingkat kesukaan (Hedonik) dan tingkat penerimaan (Skoring) terhadap rasa permen jelly daun kersen yang dilakukan oleh 30 panelis tidak terlatih. Ratarata tingkat kesukaan dan penerimaan terhadap rasa dari permen jelly ekstrak daun kersen dengan berbagai dapat dilihat pada Gambar 4 .

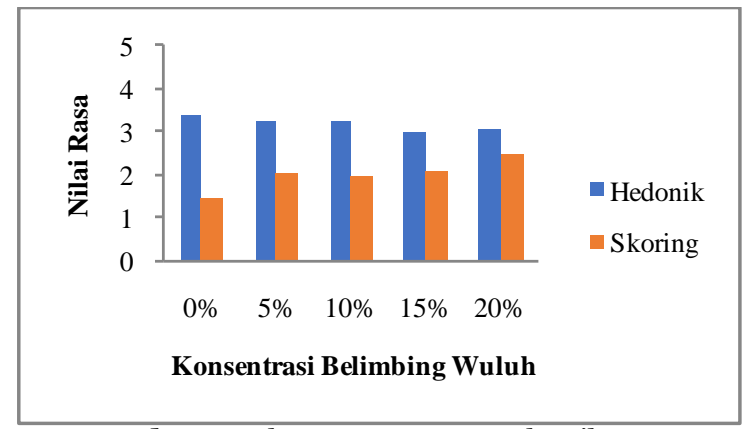

Gambar 6. Skor Rerata Organoleptik Ra sa

Gambar 6 menunjukkan rata-rata tingkat kesukaan (uji hedonik) terhadap rasa permen jelly daun kersen dengan variasi penambahan konsentrasi ekstrak belimbing wuluh berdasarkan penilaian 30 orang panelis berkisar antara 2,96 (agak suka) sampai 3,40 (agak suka). Hasil analisis variansi menunjukkan bahwa perbedaan penambahan konsentrasi ekstrak belimbing wuluh tidak berbeda nyata terhadap tingkat kesukaan panelis pada rasa permen jelly, sehingga tidak dilakukan uji lanjut. Penambahan ekstrak belimbing wuluh tidak memberikan pengaruh yang signifikan untuk segi rasa masing-masing perlakuan karena rasa sampel yang hampir sama. Meilgaard et al., (2000) menyatakan bahwa perbedaan rasa suka atau tidak suka oleh panelis tergantung kesukaan panelis terhadap suatu produk (Meilgaard et al., 2016). Sedangkan tingkat penerimaan (uji skoring) berkisar antara 1,43 (manis) sampai 2,46 (manis agak pahit). Hasil analisis variansi menunjukkan bahwa perbedaan penambahan konsentrasi ekstrak belimbing wuluh berpengaruh nyata terhadap tingkat penerimaan panelis pada rasa permen jelly daun kersen, sehingga diperlukan uji lanjut. Hasil uji lanjut duncan menunjukkan bahwa penambahan konsentrasi ekstrak belimbing wuluh o \% berbeda nyata dengan konsentrasi 5\%, 10\%, 15\% dan $20 \%$. Konsentrasi ekstrak belimbing wuluh $5 \%$, tidak berbeda nyata dengan konsentrasi 10\% dan $15 \%$ namun berbeda nyata dengan konsentrasi $20 \%$.

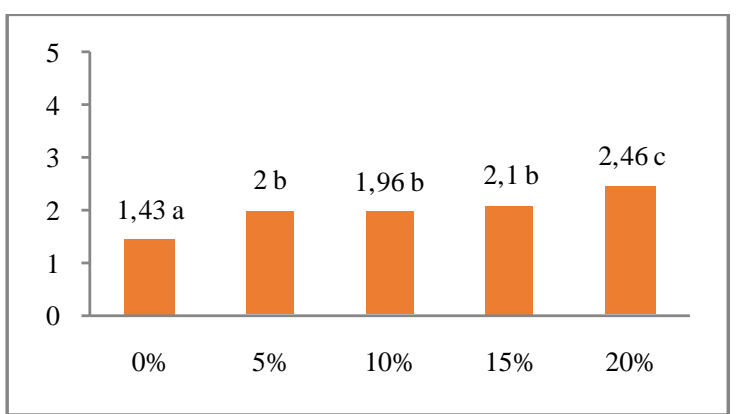

Gambar 7. Skor Rerata Organoleptik Rasa

Berdasarkan Gambar 7 dapat dilihat bahwa perbedaan konsentrasi ekstrak belimbing wuluh memiliki tingkat penerimaan yang berbeda-beda. Tingkat penerimaan yang paling tinggi berdasarkan penilaian panelis adalah perlakuan K4 (20\%) sebesar 2,46 yang masuk dalam kategori manis agak pahit, sedangkan tingkat penerimaan yang paling rendah adalah perlakuan Ko (0\%) sebesar 1,43 yang masuk dalam kategori manis. Dalam hal ini meskipun penambahan konsentrasi ekstrak belimbing wuluh berbeda-beda, kebanyakan panelis memberikan kesan rasa pahit pada setiap produk. Hal ini menunjukkan bahwa konsentrasi ekstrak belimbing wuluh yang digunakan hanya selisih 5\% dari tiap-tiap perlakuan. Rasa pahit yang dihasilkan diduga adanya kandungan tanin di dalam daun kersen, sedangkan rasa manis pada permen jelly disebabkan kandungan gula yang mendominasi produk, sehingga rasa khas yang dimiliki belimbing wuluh akan tertutupi oleh rasa pahit dari daun kersen dan rasa manis dari gula (Ahmad, Une and Bait, 2019).

\subsection{Organoleptik Tekstur}

Faktor tekstur diantaranya adalah rabaan oleh tangan, keempukan, kemudahan dikunyah serta kerenyahan makanan. Untuk itu cara pemasakan bahan makanan dapat mempengaruhi kualitas 
tekstur makanan yang dihasilkan (Meilgaard et al., 2016). Pengujian ini dilakukan untuk mengetahui tingkat kesukaan (Hedonik) dan tingkat penerimaan (Skoring) terhadap tekstur permen jelly daun kersen yang dilakukan oleh 30 panelis tidak terlatih. Rata-rata tingkatkesukaandan penerimaan terhadap tekstur dari permen jelly daun kersen dengan berbagai perbedaan konsentrasi ekstrak buah belimbing wuluh (o\% (kontrol), 5\%, 10\%, 15\% dan 20\%) yang diperoleh berdasarkan penilaian 30 orang panelis dapat dilihat pada Gambar 5 .

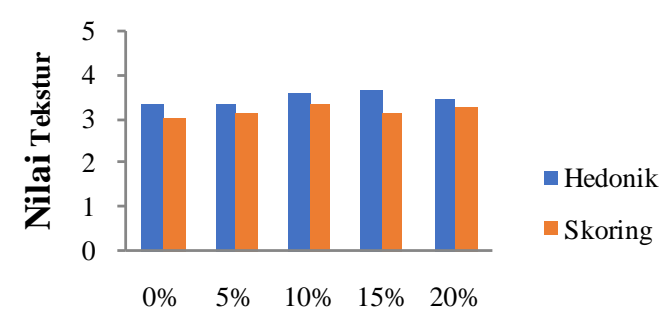

Konsentrasi Belimbing Wuluh

Gambar 8. Sk or Rerata Organoleptik Tekstur

Gambar 8 menunjukkan rata-rata tingkat kesukaan (uji hedonik) terhadap tekstur permen jelly ekstrak daun kersen dengan variasi penambahan konsentrasi ekstrak belimbing wuluh berdasarkan penilaian 30 orang panelis berkisar antara 3,33 (agak suka) sampai 3,63 (suka). Hasil analisis variansi menunjukkan bahwa perbedaan penambahan konsentrasi ekstrak belimbing wuluh tidak berbeda nyata terhadap tingkat kesukaan panelis pada tekstur permen jelly, sehingga tidak dilakukan uji lanjut.

Sedangkan tingkat penerimaan (uji skoring) berkisar antara 3,03 sampai 3,33 (agak kenyal). Hasil analisis variansi menunjukkan bahwa perbedaan penambahan konsentrasi ekstrak belimbing wuluh tidak berbeda nyata terhadap tingkat penerimaan panelis pada tekstur permen jelly daun kersen, sehingga tidak dilakukan uji lanjut.

Penambahan ekstrak belimbing wuluh tidak berpengaruh nyata terhadap tingkat kesukaan (hedonik) dan tingkat penerimaan (skoring) pada tekstur permen jelly daun kersen, Hal ini diduga kandungan pektin yang terdapat di dalam buah belimbing wuluh sedikit. Pektin adalah senyawa hidrokoloid yang berfungsi sebagai bahan penstabil, perekat dan pembentuk gel pada jelly. Menurut (Roikah et al., 2016) dengan ekstraksi 120 menit terhadap buah belimbing wuluh diperoleh rendemen pektin sebesar 1,2\%. Semakin meningkatnya konsentrasi pektin di dalam bahan maka jumlah padatan akan semakin banyak dan kadar air bahan akan menurun sehingga tekstur yang dihasilkan semakin kuat dan kenyal (Roikah et al., 2016) (Roikah 2016).

\section{SIMPULAN DAN SARAN}

Dari penelitian diatas disimpulkan bahwa pada mutu fisik, penambahan konsentrasi ekstrak belimbing wuluh tidak berpengaruh nyata terhadap warna permen jelly daun kersen. Penambahan konsentrasi ekstrak belimbing wuluh berpengaruh nyata terhadap masa simpan permen jelly ekstrak daun kersen dan perlakuan terbaik pada proses pengamatan adalah 15\%, dan $20 \%$ karena masa simpannya lebih lama dari perlakuan lainnya. Penambahan konsentrasi ekstrak belimbing wuluh tidak berpengaruh nyata terhadap tingkat kesukaan (Hedonik) serta tingkat penerimaan (Skoring) terhadap tekstur, namun mempengaruhi tingkat penerimaan panelis terhadap warna, aroma dan rasa permen jelly ekstrak daun kersen. Perlakuan terbaik terhadap tingkat penerimaan panelis untuk uji warna yaitu pada konsentrasi o\% sebesar 3,16. Aroma permen jelly terbaikyaitu pada konsentrasi 20\% sebesar 3,50. Rasa permen jelly terbaik diperoleh pada konsentrasi $20 \%$ dengan tingka tpenerimaan sebesar 2,46.

\section{DAFTAR RUJUKAN}

Ahmad, L., Une, S. and Bait, Y. (2019) 'Karakteristik Komponen Gizi, Antioksidan, dan Respon Organoleptik Bubur Jagung Tradisional Gor ontalo dengan Ekstrak Daun Kersen (Muntingia calabura L.)', agriTECH. doi: 10.22146 /agritech.28670.

Am elia, F. R. (2015) 'Penentuan Jenis Tanin dan Penetapan Kadar Tanin dari Buah Bungur Muda (Lagerstroemia speciosa Pers.) Secara Spekt ofotometri dan Paranganometri', Jurnal Ilmiah Mahasiswa Universitas Surabaya.

Andriani, W. O. R. A., Ansharullah and Asyik, N. (2018) 'KARATERISTIK ORGANOLEPTIK DAN NILAI GIZI SNACK BAR BERBASIS TEPUNG BERAS MERAH (Ory za nivara) DAN TEPUNG JAGUNG (Zea mays L.) SEBAGAI MA KANAN SELINGA N TINGGI SERAT', Jurnal Sains dan Teknologi Pangan (JSTP).

Aprilliani, N. and Ginting Suka, E (2017) Efektivitas Ekstrak Daun Belimbing Wuluh (Averrhoa Bilimbi L.) Sebagai Inhibitor Pada Baja St37 Dalam Medium Korosif $\mathrm{NaCl} 3 \%$, Jurnal Teori dan Aplikasi Fisika. doi: 10.23960/JTAF.V5 I2.1812.

Buhian, W. P. C. et al. (2016) 'Bioactive metabolite profiles and antimicrobial activity of ethanolic extracts from Muntingia calabura L. leaves and stems', Asian Pacific Journal of Tropical Biomedicine. doi: 10.1016/j.apjtb.2016.06.006.

CANDRA, S., DK, K. and Widodo, Y. (2012) 'PENGARUH PEMBERIAN EKSTRAK BUAH BELIMBING WULUH (Av errhoa blimbi L.) TERHADAP PENURUNAN KADAR GLUKOSA DARAH TIKUS WISTAR YANG DIINDUKSI ALOKSAN', Jurnal Kedokteran Diponegoro.

Fitri, dkk. (2017) 'Konsentrasi Gula dan Sari Buah Terhadap Kualitas Sirup Belimbing Wuluh (Averrhoa bilimbi L.)', JOM Faperta UR. 
Mahar Maligan, J., Dian Pratiwi, D. and Dewanti Widy aningsih, T. (2019) 'Studi Preferensi Konsumen terhadap Nasi Putih dan Nasi Jagung Putih pada Pekerja Wanita di Kantor Pemerintah Kota Malang', Indonesian Journal of Human Nutrition. doi: 10.21776/ub.ijhn.2019.006.01.5.

Marfungah, N. et al. (2019) 'PENGARUH PENAMBAHAN BUBUK KAYU MANIS (Cinnam on burmanii) TERHADAP KA RA KTERISTIK KIMIA DAN ORGANOLEPTIK PERMEN JELLY DAUN SALAM (Syzygium polyanthum)', J. Sains dan Teknologi Pangan.

MEILGAARD MORTEN, C., VANCE, C. G. and THOMAS, C. B. (2016) Sensory Evaluation Techniques fifth edition, CRC Press Taylor \& Francis Group Boca Raton, FL - USA. doi: 10.1111/j.1471-0307.2007.00330.x.

Meutia, Y. R. et al. (2015) 'Pengaruh Suhu dan Waktu Maserasi terhadap Komponen Volatil yang Terlibat pada Ekstraksi Andaliman ( Zanthoxylum acanthopodium DC )', Journal of Agro-based Industry.

'Peningkatan Nilai Tambah Daun Kersen (Muntingia Calabura L.) Menjadi Permen Jelly dan Teh Seduh' (2019) Jurnal Abdimas.

Pino, J. A., Marbot, R. and Bello, A. (2004) 'Volatile components of averrhoa bilimbi L. Fruit grown in Cuba', Journal of Essential Oil Research. doi: 10.1080/10412905.2004.9698710.

Roikah, S. et al. (2016) 'EKSTRA KSI DAN KA RAKTERISASI PEKTIN DA RI BELIMBING W ULUH (Averrhoa bilimbi,L)', Jurnal Bahan Alam Terbarukan. doi: 10.15294/jbat.v5i1 .5432.

Sinurat, E and Murniyati, M. (2014) 'Pengaruh Waktu dan Suhu Pengeringan terhadap Kualitas Permen Jeli', Jurnal Pascapanen dan Bioteknologi Kelautan dan Perikanan. doi: $10.15578 /$ jpbkp.v9i2.106.

Tyas Eka, V. (2009) 'UJI EFEKTIFITAS JUS BUAH KERSEN (Muntingia calabura L.) TERHADAP PENURUNAN KADAR GLUKOSA DARAH PADA TIKUS PUTIH (Rattus n orv egicus)', Biology.

Wahyuni, R. (2010) 'Optimasi Pengolahan Kembang Gula Jelly Campuran Kulit Dan Daging Buah Naga Super', OPTIMASI PENGOLAHAN KEMBANG GULA JELLY CAMPURAN KULIT DAN DAGING BUAH NAGA SUPER MERAH (Hylocereus costaricens is) DAN PRAKIRAAN BIAYA PRODUKSI Rekna.

Zakaria, Z. A. et al. (2011) 'In vivo antiulcer activity of the aqueous extract of Bauhinia purpurea leaf', Journal of Ethnopharmacology. doi: 10.1016/j.jep.2011.07.038. 